Syntax Literate: Jurnal Ilmiah Indonesia p-ISSN: 2541-0849

e-ISSN: 2548-1398

Vol. 5, No. 8, Agustus 2020

\title{
PERAN KUNJUNGAN KELUARGA TERHADAP KONDISI PSIKOLOGIS NARAPIDANA DI LAPAS KELAS IIB PANGAKALAN BUN
}

\section{Bahtiyar Mandala Sutra}

Politeknik Ilmu Pemasyarakatan Depok, Indonesia

Email: bahtiyarmandalasutra@gmail.com

\section{Abstract}

The research focuses on the benefits of conducting family visits in Lapas Kelas IIB Pangkalan Bun because each Correctional Technical Service Unit has a different culture. As for research is descriptive analysis with a qualitative approach. Based on the result of the research conducted, it is known that the implementation of family visits for prisoners in Lapas Kelas IIB Pangkalan Bun has a positive influence on the psychological condition of prisoners if compared to prisoners who are rarely or never visited. Other than that, the conduct of family visits is also a means of entertainment for prisoners, among other things, the prisoners become more confident and enthusiastic about life. It also functions as an effort to anticipate the emergence of chaos or the possibility of escape. But in carrying out family visits there are several obstacles, that is: time factor, domicile, and economy, the tendency for a feeling of shame and careless attitude from the prisoner's family. Various problems were found in carrying out family visits, some alternative solutions to problems can be done in a way: 1) extension of time when visit, 2) the participation of officers is further enhanced in following the development of prisoners so that early prevention can be done on matters that can affect the psychological condition of prisoners, and it needs to be done individually (personal approach) towards prisoners who experience psychological disorders due to never being visited, 3) it is necessary to have a mass visit on a particular day, such as on the anniversary of the Republic of Indonesia independence day by giving an invitation to each family of prisoners.

Keywords: family visits; psychological condition of prisoners.
Abstrak
Penelitian ini berfokus pada manfaat dalam pelaksanaan kunjungan keluarga di Lapas Kelas IIB Pangkalan Bun karena setiap Unit Pelayanan Teknis Pemasyarakatan memiliki budaya yang berbeda. Adapun metode penelitian yang digunakan adalah analisis yang bersifat deskriptif dengan pendekatan kualitatif. Berdasarkan hasil penelitian yang dilakukan diketahui bahwa pelaksanaan kunjungan keluarga bagi narapidana di Lapas Kelas IIB Pangkalan Bun membawa pengaruh positif bagi kondisi psikologis narapidana jika dibandingkan dengan narapidana yang jarang ataupun tidak pernah dikunjungi. Selain itu, pelaksanaan kunjungan keluarga juga sebagai sarana hiburan bagi narapidana, antara lain narapidana menjadi lebih percaya diri dan mempunyai semangat hidup. Hal ini pula berfungsi sebagai upaya antisipasi timbulnya kekacauan atau terjadinya 
kemungkinan pelarian. Namun dalam pelaksanaan kunjungan keluarga terdapat beberapa kendala, yaitu: faktor waktu, domisili dan ekonomi, kecenderungan adanya perasaan malu dan sikap kurang peduli dari keluarga narapidana. Berbagai permasalahan ditemukan dalam pelaksanaan kunjungan keluarga, beberapa alternatif pemecahan masalah dapat dilakukan dengan cara : 1) perpanjangan waktu ketika kunjungan, 2) peran serta petugas lebih ditingkatkan dalam mengikuti perkembangan narapidana, sehingga dapat dilakukan pencegahan dini terhadap halhal yang dapat mempengaruhi kondisi psikologis narapidana, serta perlu dilakukan pendekatan secara individual (personal approach) terhadap narapidana yang mengalami gangguan psikologis akibat tidak pernah dikunjungi, 3) perlu diadakan kunjungan massal pada hari tertentu, seperti pada Hari Besar Peringatan Kemerdekaan RI dengan memberikan undangan pada setiap keluarga narapidana.

Kata kunci : Kunjungan Keluarga; Kondisi Psikologis Narapidana

\section{Pendahuluan}

Akhir masa pemerintahan Orde Baru memunculkan harapan bahwa Indonesia akan berkembang menjadi negara hukum demokratis yang menghormati dan menjunjung tinggi rule of law. Dalam rangka mewujudkan hal tersebut telah diambil berbagai langkah formal, antara lain, menambahkan Bab XA ke dalam konstitusi (UUD 1945) dan menandatangani instrumen hak asasi manusia internasional seperti Kovenan Internasional tentang Hak-hak Sipil dan Politik (ICCPR). Dengan itu semua Indonesia baik secara eksternal maupun internal mengikatkan diri untuk bertindak sejalan dengan (tuntutan) rule of law. Kewajiban serupa juga muncul berkenaan dengan (pengembangan dan penegakan) hukum pidana di Indonesia. Kewajiban yang disebut terakhir mencakup dua hal: pertama kewajiban untuk mengembangkan hukum pidana yang fungsional, dan kedua, kewajiban untuk memberikan jaminan (dan perlindungan) hak (dasar) kepada setiap orang, tanpa kecuali dan tanpa memandang perbedaanperbedaan di antara mereka (Pohan et al., 2012).

Dalam Pasal 1 ayat (3) Undang-undang Dasar 1945 telah ditegaskan bahwa Indonesia adalah negara Hukum. Dalam kehidupan bernegara, salah satu yang harus ditegakkan adalah suatu kehidupan hukum di dalam kehidupan bermasyarakat. Pandangan ini diyakini tidak hanya disebabkan dianutnya paham negara hukum, melainkan lebih melihat secara kritis kecenderungan yang terjadi di dalam kehidupan bangsa Indonesia yang berkembang kearah masyarakat modern (Harefa, 2019). Dalam negara hukum setiap warga negara akan mendapatkan perlindungan dari negara atau pemerintah dari setiap tindakan atau perbuatan yang berdampak terhadap ketidakstabilan dalam masyarakat. Ketidakstabilan dalam masyarakat adalah akibat dari perilaku menyimpang dari oknum masyarakat. Perilaku menyimpang tersebut dimaknai sebagai sebuah kejahatan. Kejahatan akan selalu ada dan ditemukan di dalam masyarakat manapun juga, meskipun masyarakat itu sendiri tidak pernah mengharapkan kehadirannya (Devilla \& Tarmizi, 2018).

Eksistensi pemasyarakatan sebagai instansi penegak hukum telah diatur secara tegas dalam Undang-Undang Nomor 12 Tahun 1995 tentang Pemasyarakatan 
(Videbeck, 2008). Dalam Pasal 8 ayat (1) menyatakan bahwa petugas pemasyarakatan merupakan pejabat fungsional penegak hukum yang melaksanakan tugas di bidang pembinaan, pengamanan dan pembimbingan Warga Binaan Pemasyarakatan. Pelaksanaan tugas dan fungsi pemasyarakatan harus dilandaskan pada aturan hukum yang berlaku agar pemenuhan dan perlindungan HAM dapat direalisasikan (Datunsolang, 2013). Lembaga Pemasyarakatan merupakan bagian dari sistem peradilan pidana yang mengarah pada tujuan resosialisasi, sebagaimana diatur dalam Pasal 3 Undang-undang Nomor 12 Tahun 1995 tentang Pemasyarakatan dinyatakan: "Sistem pemasyarakatan berfungsi menyiapkan Warga Binaan Pemasyarakatan agar dapat berintegrasi secara sehat dengan masyarakat, sehingga dapat berperan kembali sebagai anggota masyarakat yang bebas dan bertanggung jawab”. (Utami, 2017).

Secara filosofis pemasyarakatan adalah sistem pemidanaan yang sudah jauh bergerak meninggalkan filosofis retributive (pembalasan), deterrence (penjeraan) dan resosialiasi. Dengan kata lain pemidanaan tidak ditujukan untuk membuat derita sebagai bentuk pembalasan, tidak juga ditujukan untuk membuat jera dengan penderitaan serta tidak mengasumsikan terpidana sebagai seseorang yang kurang sosialisasinya (Dwiatmojo, 2014). Selain itu, perlu diketahui bahwa fungsi Lembaga Pemasyarakatan, yang secara filosofis berbeda dengan penjara, merupakan upaya untuk menghindari terjadinya proses penghukuman yang tidak manusiawi. Salah satu upaya tersebut adalah mencegah terjadinya prisonisasi atau proses belajar kejahatan serta meminimalisir penderitaan dalam pemenjaraan. Menurut Didin Sudirman, adanya hak-hak Narapidana yang dilindungi oleh Undang-undang Nomor 12 Tahun 1995 tentang Pemasyarakatan merupakan upaya untuk memperkecil kemungkinan terjadinya prisonisasi dan stigmatisasi masyarakat (Michael, 2015).

Kehidupan narapidana di Lembaga Pemasyarakatan merupakan bentuk dari konsekuensi hukuman atas perilaku melanggar hukum yang pernah dilakukan (Pratama, 2016). Perlu diketahui di dalam lembaga pemasyarakatan, narapidana menghadapi sejumlah permasalahan yang sangat berpengaruh terhadap psikologis mereka. Kehidupan yang dijalani seorang narapidana selama berada di penjara, membuat dirinya menghadapi berbagai masalah psikologis antara lain kehilangan keluarga, kehilangan kontrol diri, kehilangan model, dan kehilangan dukungan. Selain itu tembok lapas juga merenggut kebebasan atau kemerdekaan bergerak. Narapidana juga akan mengalami kehidupan yang lain dengan kehidupan yang sebelumnya antara lain kehilangan hubungan dengan lawan jenis, kehilangan hak untuk menentukan segala sesuatunya sendiri, kehilangan hak memiliki barang, kehilangan hak mendapat pelayanan dan kehilangan rasa aman. Berbagai permasalahan tersebut merupakan gangguan yang akan mempengaruhi narapidana baik secara fisik maupun psikologis (Meilina, 2013).

Sebuah studi oleh Wuryansari dan Subandi menjabarkan mengenai faktor-faktor risiko apa saja yang memengaruhi rendahnya kesehatan mental narapidana di lingkungan Lapas. Faktor-faktor tersebut antara lain kondisi kepadatan atau kesesakan (overcrowding), bentuk-bentuk kekerasan, kurangnya privasi, kurangnya aktivitas yang berarti, isolasi dari jaringan sosial, ketidakamanan tentang prospek masa depan dan 
pelayanan kesehatan yang tidak memadai, terutama layanan kesehatan mental di Lapas (Wuryansari \& Subandi, 2019). Penelitian lain dari (Wati, 2014) turut mengungkap bahwa status narapidana (residivis atau non-residivis), menjadi pengaruh faktor risiko narapidana mengalami depresi. Perubahan hidup, hilangnya kebebasan dan hak-hak yang semakin terbatas serta kehidupan yang membuat mereka harus terpisah dari keluarga dan hidup bersama narapidana lain, hal ini tentunya akan memicu timbulnya stres.

Hasil penelitian yang dilakukan oleh Holmes dan Rahe menguatkan bahwa kehidupan di dalam lembaga permasyarakatan memang tidak mudah dan terdapat berbagai permasalahan. Terbukti hukuman penjara menempati urutan keempat dalam skala urutan pengalaman hidup yang menimbulkan stres. Bahkan menurut Cohen dan Taylor menyebut kehidupan di dalam lembaga permasyarakatan atau penjara sebagai keruntuhan hidup menyeluruh (massive life disruption) (Hairina \& Komalasari, 2017). Oleh sebab itu, adanya kunjungan keluarga merupakan salah satu hak narapidana, seperti tercantum dalam Undang-Undang Nomor 12 Tahun 1995 Pasal 1 Butir (h) yaitu "Narapidana berhak menerima kunjungan keluarga, penasehat hukum, atau orang tertentu lainnya" (UU Nomor, 12 C.E.). Pelaksanaan kunjungan tersebut merupakan suatu hal yang terkait erat dengan pemulihan atau rehabilitasi kondisi psikologis narapidana atas dampak dari pemidanaan yang ia alami.

Sistem pemasyarakatan bertujuan untuk mengendalikan Warga Binaan Pemasyarakatan sebagai warga yang baik dan untuk melindungi masyarakat terhadap kemungkinan diulanginya lagi tindak pidana, maka pelaksanaan Sistem Pemasyarakatan ini menitik beratkan pada usaha-usaha perawatan, pembinaan, pendidikan dan bimbingan bagi warga binaan. Adapun hak-hak yang dimiliki oleh Warga Binaan Pemasyarakatan (WBP) yang diatur dalam Pasal 14 Ayat (1) Undang-Undang Nomor 12 Tahun 1995 salah satunya berkaitan dengan hak menerima kunjungan keluarga. Ini berarti narapidana berhak menerima kunjungan keluarga di dalam Lembaga Pemasyarakatan yang di fasilitasi oleh Lembaga Pemasyarakatan itu sendiri dan hak untuk menerima kunjungan keluarga ini juga termasuk salah satu dari asas pembinaan pemasyarakatan yang sesuai dengan Pasal 5 Undang-Undang Nomor 12 Tahun 1995 tentang Pemasyarakatan yang menyatakan bahwa narapidana harus tetap didekatkan dan dikenalkan dengan masyarakat serta tidak boleh diasingkan dari masyarakat (Hilton, 2019). Selama mengalami pemidanaan narapidana harus dikenalkan dengan masyarakat dan tidak boleh diasingkan. Tujuan di atas dimaksudkan untuk meningkatkan kualitas warga binaan pemasyarakatan agar menyadari kesalahan, memperbaiki diri, dan tidak mengulangi tindak pidana sehingga dapat diterima kembali di masyarakat. Selain itu narapidana diharapkan juga dapat berperan aktif dalam pembangunan, dan dapat hidup secara wajar sebagai warga negara yang baik dan bertanggung jawab (Permana \& Rudatyo, 2017).

Narapidana merupakan populasi yang rentan terhadap timbulnya berbagai permasalahan psikologis. Narapidana yang sedang menjalani hukuman pidana tidak hanya mengalami hukuman secara fisik, namun juga mengalami hukuman secara 
psikologis. Dampak fisik dan psikologis yang dialami oleh narapidana dapat membuat narapidana merasakan perasaan tidak bermakna (meaningless), yang ditandai dengan perasaan hampa, gersang, bosan dan penuh dengan keputusasaan (Nurrahma, 2013). Menjadi narapidana adalah stresor kehidupan yang berat bagi pelakunya. Perasaan sedih pada narapidana setelah menerima hukuman serta berbagai hal lainnya seperti rasa bersalah, hilangnya kebebasan, perasaan malu, sangsi ekonomi dan sosial serta kehidupan dalam penjara yang penuh dengan tekanan psikologis dapat memperburuk dan mengintensifkan stresor sebelumnya. Keadaan tersebut bukan saja mempengaruhi penyesuaian fisik tetapi juga psikologis individu (Hairina \& Komalasari, 2017).

Berdasarkan uraian diatas, Peneliti melakukan pengamatan mengenai manfaat pelaksanaan kunjungan keluarga di Lapas Kelas IIB Pangkalan Bun, karena pelaksanaan kunjungan keluarga dianggap sangat penting sebagai suatu sarana yang menghubungkan narapidana dengan keluarganya. Dengan segala keterbatasan yang dialami oleh para pelanggar hukum, maka akan mudah ditemui narapidana dengan kondisi psikologis yang menyedihkan. Namun, hal ini dapat diatasi dengan adanya program kunjungan bagi narapidana. Dengan tujuan pelaksanaan kunjungan keluarga dapat diaplikasikan dan membawa pengaruh positif bagi kondisi psikologis narapidana agar keamanan dan ketertiban di Lapas Kelas IIB Pangkalan Bun selalu kondusif.

\section{Metode Penelitian}

Penelitian ini menggunakan metode analisis deskriptif dengan pendekatan kualitatif, yaitu menggambarkan secara langsung pelaksanaan untuk mendapatkan informasi mengenai pelaksanaan kunjungan keluarga, manfaat serta perannya terhadap kondisi psikologis narapidana di Lapas Kelas IIB Pangkalan Bun.

Untuk mendapatkan data yang akurat penulis melakukan peninjauan dan pengamatan secara langsung kelapangan dengan melaksanakan kegiatan Kuliah Kerja Nyata (K2N) dan Pengabdian Masyarakat di Lapas Kelas IIB Pangkalan Bun, serta meninjau secara langsung bidang yang berhubungan dengan penulisan ini.

Selain melakukan pengamatan langsung, penulis melakukan wawancara secara langsung dan mendalam kepada informan yaitu narapidana dan keluarga sebagai penunjang data yang diperlukan.

Penulis menggunakan berbagai media bacaan sebagai sumber data untuk menambah pemahaman serta pendalaman teori terhadap permasalahan yang akan dibahas.

\section{Hasil dan Pembahasan}

\section{A. Manfaat Kunjungan Keluarga}

Pelaksanaan program kunjungan keluarga merupakan suatu upaya dalam mewujudkan Reintegrasi Sosial warga binaan pemasyarakatan (WBP), yaitu pulihnya kesatuan hubungan warga binaan pemasyarakatan baik secara pribadi, anggota masyarakat, maupun sebagai insan Tuhan. Dalam pelaksanaan kunjungan 
keluarga tentunya terdapat pengaruh positif dan negatif. Adapun pengaruh positif tersebut dapat memberikan manfaat sebagai berikut :

1. Manfaat Bagi Narapidana

a. Mendapatkan buah tangan dari keluarga yang berkunjung

Pada saat pelaksanaan kunjungan, pihak Lapas Kelas IIB Pangkalan Bun memperbolehkan keluarga yang mengunjungi untuk membawakan buah tangan atau oleh-oleh bagi narapidana karena pada umumnya buah tangan yang diterima oleh narapidana yaitu berupa makanan, snack, buah-buahan atau suplemen lain sebagai penambah kualitas makanan dan tentunya sesuai dengan aturan yang berlaku.

b. Mengurangi beban psikis akibat hilang kemerdekaan

Pidana penjara merupakan pidana hilang kemerdekaan atau lebih tepatnya adalah pidana pencabutan kemerdekan terhadap seseorang disebabkan oleh tindakan kriminal atau kejahatan yang telah dilakukannya. Hal tersebut mengakibatkan terampasnya sebagian hak-hak narapidana sebagai seorang individu dimana mereka akan merasakan kehilangan hak dan kebebasan untuk mengatur diri sendiri, kehilangan hubungan sosial dengan masyarakat dan keluarganya, serta kehilangan mata pencahariannya. Semua itu akan menimbulkan beban penderitaan psikis bagi narapidana. Akibat dari adanya beban penderitaan narapidana dapat menimbulkan kecemasan, stres, depresi ataupun kegelisahan yang berlebihan terhadap hal-hal yang tidak pasti.

Walaupun pidana penjara merupakan sebuah konsekuensi dari tindak pidana atau kejahatan yang telah dilakukannya, namun hal itu tetap saja akan menimbulkan konflik batin yang sangat parah bagi narapidana karena segala keterbatasannya di dalam Lembaga Pemasyarakatan. Konflik tersebut terjadi karena adanya pertentangan batin dalam beradaptasi dengan pola kehidupan baru yang tidak menyenangkan yang sangat berbeda dengan pola kehidupan narapidana sebelum masuk ke dalam Lembaga Pemasyarakatan terlebih bagi seseorang yang baru pertama kali masuk penjara pasti menimbulkan goyangan kejiwaan yang lebih.

Terpisah dengan keluarga dan teman-teman dekat merupakan salah satu luka yang sangat parah dari sebuah pidana penjara. Oleh sebab itu, manfaat dari pelaksanaan kunjungan keluarga ini sangat tampak jelas karena keluarga sebagai orang yang paling dekat dengan narapidana akan menciptakan suasana baru dan perlahan dapat mengobati luka tersebut dimana mereka dapat mencurahkan isi hatinya dan segala keluh kesah, melepas rasa rindu, mendapatkan nasihat-nasihat serta dorongan semangat sehingga narapidana merasa terhibur dan dapat mengurangi beban psikis yang dirasakan akibat pemidanaan yang dijalaninya.

c. Menumbuhkan rasa percaya diri dan harga diri narapidana 
Adanya penilaian atau citra yang cenderung negatif dari keterlibatan seseorang dengan hukum adalah pengaruh sosial dari masyarakat. Banyak masyarakat yang masih menilai bahwa seorang narapidana adalah sampah masyarakat yang patut dijauhi dan diasingkan dari masyarakat supaya tidak lagi mengganggu keamanan dan ketertiban umum. Ketika narapidana harus menjalani masa pidananya di Lembaga Pemasyarakatan sekaligus mendapat celaan dari masyarakat dan lingkungannya, otomatis mereka akan merasa tidak berharga, berdosa dan tidak berguna bahkan merasa benci terhadap dirinya sendiri yang pada akhirnya akan mengakibatkan narapidana merasa sangat terpuruk dan hilangnya harga diri serta rasa kepercayaan terhadap diri sendiri. Selain itu bentuk-bentuk perlakuan narapidana yang didapat di dalam Lembaga Pemasyarakatan membuat narapidana merasa terampas harga dirinya, misalnya penyediaan tempat mandi yang terbuka untuk mandi bersama-sama, WC yang terbuka, kamar tidur (sel) yang hanya berpintu dari besi dan lain sebagainya.

Pada saat kunjungan keluarga bagi narapidana dimana terjadi suatu kontak fisik karena pada ruang kunjungan tidak terdapat pembatas/sekat apapun, hal tersebut akan membentuk sebuah jalinan hubungan sosial yang positif antara narapidana dengan keluarganya sebagai komunitas terkecil dari masyarakat. Hal ini menandakan bahwa keluarga narapidana masih peduli dan memberikan perhatian serta kasih sayang, sehingga dapat membawa pengaruh baik bagi kondisi psikis narapidana. Bagi narapidana yang sudah menikah dan berkeluarga, tentunya memiliki kebutuhan dan harapan untuk masih mendapatkan pengakuan dari suami/istri dan anak-anaknya tentang peranannya dalam kehidupan rumah tangga. Oleh sebab itu, pelaksanaan kunjungan keluarga sangat penting karena narapidana merasa harga dirinya terangkat kembali karena mereka masih diakui, terikat serta dapat berperan sebagai suami/istri ataupun ayah/ibu dari anak-anaknya walaupun mereka tidak berada di tengahtengah keluarganya.

d. Dapat mengetahui keadaan dan perkembangan keluarganya dan masyarakat luar

Salah satu manfaat kunjungan keluarga adalah alat atau sarana bagi narapidana untuk bertemu dengan keluarga. Program kunjungan keluarga adalah waktu yang diberikan bagi narapidana untuk berhubungan, berkomunikasi dan mengadakan kontak fisik secara langsung dengan anggota keluarganya. Pada saat inilah mereka dapat mengetahui dan mengikuti perkembangan situasi dan kondisi yang terjadi baik dalam keluarganya maupun masyarakat umum di luar tembok Lembaga Pemasyarakatan. Hal ini akan bermanfaat sebagai bekal narapidana untuk menyesuaikan diri dengan perkembangan dan perubahan-perubahan yang 
terjadi dalam keluarganya ataupun masyarakat luar ketika pada akhirnya mereka kembali ke dalam masyarakat.

2. Manfaat bagi keluarga narapidana

a. Dapat memberikan dukungan moral kepada narapidana

Kehilangan sebagian hak-hak narapidana sebagai seorang individu dimana mereka akan merasakan salah satunya kehilangan kebebasan bergerak. Semua itu akan menimbulkan beban penderitaan psikis bagi narapidana. Hal ini merupakan suatu pukulan yang berat dan berakibat menurunnya tingkat kepercayaan diri pada narapidana. Dalam hal ini, keluarga sebagai salah satu elemen pendukung dalam sistem pemasyarakatan berfungsi mendorong narapidana agar tetap tegar dan dapat berperan aktif dalam menjalani program pembinaan di Lembaga Pemasyarakatan. Dengan adanya kunjungan dari keluarga narapidana, maka keluarga dapat secara langsung bertemu untuk memberikan dukungan moral dan semangat kepada narapidana supaya narapidana merasa tenang menjalani masa pidananya di dalam Lembaga Pemasyarakatan.

b. Dapat mengetahui keadaan dan perkembangan narapidana

Masih banyak masyarakat yang menganggap bahwa penjara adalah tempat menyeramkan yang identik dengan kekerasan dan penyiksaan. Sebagian masyarakat dan keluarga narapidana menganggap bahwa petugas pemasyarakatan adalah tukang pukul, tukang peras, kejam yang selalu mengeksploitasi dan mendiskriminasi serta memperlakukan narapidana dengan sikap sewenang-wenang. Penilaian dan anggapan miring seperti ini merupakan stigma masyarakat berdasarkan adanya pengalaman realistis seseorang yang telah merasakan hal tersebut, tentunya jauh sebelum terwujudnya sistem pemasyarakatan. Hal ini beredar dari mulut ke mulut, sehingga menjadikan citra yang buruk terhadap diri seorang petugas di Lembaga Pemasyarakatan. Namun dengan adanya kunjungan keluarga memungkinkan pihak keluarga berkomunikasi secara langsung dengan narapidana untuk dapat menilai seberapa baik tugas perawatan dan pembinaan yang diberikan kepada narapidana sehingga dapat menghapus penilaian dan anggapan negatif sebagian masyarakat tentang kondisi narapidana selama berada di dalam Lembaga Pemasyarakatan.

c. Dapat memelihara tali silaturahmi dengan narapidana

Pengakuan dan perhatian dari keluarga merupakan salah satu poin yang sangat penting bagi narapidana selama ia menjalani masa pidananya di dalam Lembaga Pemasyarakatan. Sekalipun latar belakang terjadinya sebagian tindak pidana adalah karena adanya pola asuh keluarga yang salah dan terjadinya ketidakharmonisan di lingkungan keluarga, keluarga 
tetap memiliki kewajiban moral untuk tetap memberikan perhatian dan mengakui keberadaan narapidana sebagai bagian dari keluarganya. Dengan demikian, tali silaturahmi dan hubungan keluarga tetap dapat terjalin sehingga keluarga tidak merasa kehilangan salah satu anggota keluarga. Demikian juga dengan narapidana tetap merasa mempunyai keluarga yang masih peduli dan perhatian terhadap dirinya.

3. Manfaat bagi pihak Lembaga Pemasyarakatan

a. Dapat mengurangi pikiran-pikiran negatif narapidana dan hasrat untuk melarikan diri dari Lembaga Pemasyarakatan.

Hidup dalam kondisi yang serba dibatasi oleh tembok dan aturanaturan yang mendetail menyebabkan narapidana merasa terkekang dan menderita. Semakin banyak dan besarnya pembatasan tersebut, maka ketidakmampuan narapidana yang bersangkutan untuk menanggung derita tersebut juga menjadi semakin tinggi. Akibatnya, keinginan dan hasratnya untuk melepaskan ketegangan dan gejolak pertentangan dalam jiwanya melalui berbagai tindakan, di antaranya seperti melakukan percobaan bunuh diri, bahkan melarikan diri dari Lembaga Pemasyarakatan akan menjadi semakin besar pula. Seperti yang telah diuraikan sebelumnya, bahwa kunjungan keluarga akan membawa ketenangan jiwa maupun mengurangi gejolak pertentangan dalam hatinya, maka hal ini dapat dijadikan sebagai salah satu unsur pendukung dalam mencegah hasrat dan keinginan mereka untuk melakukan tindakan-tindakan negatif tersebut.

b. Dapat mengurangi tingkat pelanggaran narapidana sehingga dapat menciptakan suasana yang tertib, aman dan kondusif di dalam Lembaga Pemasyarakatan.

Pada umumnya narapidana merasa berdosa, tidak berguna dan menyesal kepada keluarga mereka atas perbuatan melanggar hukum yang telah dilakukannya. Oleh karena itu, dengan adanya kunjungan dari keluarga narapidana akan tercipta suatu hubungan timbal balik yang membawa pengaruh positif yaitu ketenangan batin bagi narapidana. Jika mereka dapat mengatasi konflik batin itu melalui komunikasi secara langsung dengan keluarganya maka untuk menebus rasa bersalahnya itu mereka akan berusaha bertanggung jawab atas semua perbuatannya dengan menjalani masa pidananya di Lembaga Pemasyarakatan dan mematuhi peraturan yang ada dengan sebaik mungkin walaupun dengan rasa terpaksa, sedih dan malu sehingga dapat meminimalisir tingkat pelanggaran yang mungkin mereka lakukan.

Narapidana pada umumnya merupakan pihak yang berseberangan dengan kepentingan pengamanan. Adapun petugas dalam fungsinya sebagai tenaga pengamanan selalu merasa sewaktu-waktu mudah untuk diserang, dikelabui, diperdayakan oleh narapidana sehingga dapat 
mengancam secara langsung baik terhadap karir maupun terhadap keselamatan jiwanya.

Oleh karenanya, ketika anggapan negatif terhadap narapidana semacam itu dapat dihapuskan dalam setiap diri petugas dan toleransi terhadap hal-hal yang bersifat kondisional tetap dilaksanakan, salah satunya dengan adanya kunjungan dari keluarga narapidana, maka suasana di Lembaga Pemasyarakatan akan tertib, aman dan kondusif bagi terlaksananya program pembinaan dan bimbingan pekerjaan dalam rangka menciptakan sosok manusia yang berguna dan bertanggung jawab.

\section{B. Pengaruh Psikologis Narapidana Berkaitan dengan Kunjungan Keluarga}

Perbedaan perilaku dan kondisi psikologis pada narapidana yang jarang dikunjungi pun tampak jelas. Narapidana yang jarang dikunjungi seringkali terlihat murung atau melamun, bersikap penyendiri dan narapidana yang tidak pernah dikunjungi terlihat tertutup, susah bergaul dan berkomunikasi dengan narapidana yang lain. Bahkan mereka seringkali merasa rendah diri dan merasa iri terhadap narapidana yang sering dikunjungi, serta menunjukkan sikap yang kurang antusias terhadap aturan yang ada. Terkadang dapat ditemukan perilaku hiperaktif, hal ini terkadang mereka tampilkan sebagai sarana untuk mendapatkan perhatian dari orang-orang di sekelilingnya.

Pada umumnya narapidana yang tidak pernah dikunjungi adalah karena faktor jarak yang jauh antara tempat domisili keluarga narapidana (terkadang narapidana bukanlah warga asli kota Pangkalan Bun atau terkadang karena minimnya faktor ekonomi. Adapula kecenderungan adanya perasan malu dari keluarga narapidana karena adanya stigmatisasi dari masyarakat dan adanya anggapan bahwa nama baik keluarga telah tercoreng akibat perilaku anggota keluarga mereka yang akhirnya menjadi narapidana.

Dari pengamatan akan kenyataan yang sesungguhnya terjadi dalam Lapas Kelas IIB Pangkalan Bun timbul kecenderungan bahwa semakin sering narapidana dikunjungi, maka ia menunjukan sikap yang mengarah pada keteraturan dan ketertiban perilaku dan perubahan kepercayaan diri narapidana tersebut. Hal ini didukung pula dengan pendapat para petugas yang lebih memahami sifat dan perilaku narapidana. Mereka sangat setuju dengan adanya kunjungan keluarga, karena selain sebagai sarana hiburan bagi narapidana, hal ini pula berfungsi sebagai upaya antisipasi timbulnya kekacauan atau terjadinya kemungkinan pelarian. Demikian pengaruh positif yang didapat dari pelaksanaan kunjungan keluarga.

\section{Kendala Dalam Pelaksanaan Kunjungan Keluarga}

Berdasarkan hasil penelitian yang dilakukan di Rumah Tahanan Negara Kelas IIB Balikpapan, terdapat beberapa faktor yang menjadi kendala pelaksanaan kunjungan keluarga. Adapun yang menjadi kendala dalam kaitannya dengan kondisi psikologis narapidana adalah sebagai berikut : 
1. Faktor waktu, domisili dan ekonomi dari pihak keluarga narapidana

Lembaga Pemasyarakatan Kelas IIB Pangkalan Bun berada di tengahtengah kota Pangkalan Bun, namun banyak narapidana dan keluarganya narapidana berasal dari kota di luar Pangkalan Bun seperti Sukamara, Lamandau, Sungai Rangit dan sekitarnya yang memerlukan jarak tempuh cukup jauh dari kota Pangkalan Bun. Sehingga untuk datang mengunjungi keluarganya di Lembaga Pemasyarakatan Kelas IIB Pangkalan Bun memerlukan waktu yang cukup banyak. Selain itu, banyak pula narapidana yang berasal dari keluarga kurang mampu, dengan domisili mereka yang jauh dan dengan keadaan ekonomi yang kurang memadai mereka memilih hanya sesekali saja bahkan tidak pernah mengunjungi keluarganya, dikarenakan selain memerlukan waktu dan tenaga yang banyak juga memerlukan biaya yang banyak.

2. Kecenderungan adanya perasan malu dan sikap kurang peduli dari keluarga narapidana

Kekecewaan yang dirasakan oleh keluarga narapidana akibat dari perbuatan yang dilakukan oleh anggota keluarganya merupakan hal yang tidak dapat dipungkiri. Adanya stigmatisasi dari masyarakat dan adanya anggapan bahwa nama baik keluarga telah tercoreng akibat perilaku anggota keluarga mereka yang akhirnya menjadi narapidana membuat adanya perasaan malu untuk mengakui dan menerima kenyataan bahwa anggota keluarga mereka berada di Lembaga Pemasyarakatan Negara. Selain itu juga, adanya sikap tidak peduli bahkan sampai tidak mau menganggap mereka sebagai bagian dari anggota keluarga lagi. Menurut hasil pengamatan penulis dari sikap, perasaan dan keterangan yang diungkapkan oleh narapidana yang tidak pernah dikunjungi keluarganya itu, mereka cenderung bersikap masa bodoh dan acuh tak acuh terhadap keadaan narapidana yang lain. Namun dibalik sikap mereka tersebut, sebenarnya mereka sedang merasakan kegelisahan karena tidak pernah dikunjungi keluarganya. Walaupun mereka tetap mengikuti kegiatan pembinaan yang diselenggarakan oleh pihak Lembaga Pemasyarakatan dan tidak bertingkah laku aneh, namun kegelisahan itu tetap terlihat pada raut muka narapidana ketika diajukan pertanyaan mengenai kunjungan keluarga. Hal tersebut dapat membuat narapidana gelisah, cemas, kecewa dan sedih karena walaupun jarak tempuh dari rumah ke Lembaga Pemasyarakatan tidak terlalu jauh namun keluarganya tidak pernah menyempatkan diri untuk membesuk mereka.

\section{Analisa Pemecahan Masalah}

Pemasyarakatan diartikan sebagai suatu sistem yang merupakan rangkaian penegakkan hukum yang bertujuan agar WBP menyadari kesalahannya, memperbaiki diri dan tidak mengulangi tindak pidana, sehingga dapat diterima kembali dilingkungan masyarakat, serta dapat berperan aktif dalam pembangunan dan dapat hidup secara wajar sebagai warga yang baik dan bertanggung jawab. Hal ini dapat terwujud tentunya perlu didukung oleh elemen-elemen Pemasyarakatan 
yaitu, warga binaan pemasyarakatan (WBP), petugas Pemasyarakatan dan masyarakat sendiri, karena hanya melalui kerjasama dari ketiga unsur/elemen tersebut tugas pemasyarakatan dapat dikatakan berhasil.

Dari permasalahan yang penulis kemukakan di atas, penulis mencoba menganalisa permasalahan tersebut untuk kemudian dikembangkan menjadi sebuah pemecahan masalah.

Seperti yang telah diungkapkan diatas bahwa jika perasaan tidak nyaman dan gelisah yang dialami narapidana terus berakumulasi dan tidak dapat dikendalikan lagi maka akan dikhawatirkan terjadinya gangguan psikologis yang sifatnya destruktif bagi kejiwaan narapidana. Oleh karena itu, pelaksanaan kunjungan ini adalah salah satu solusi untuk mengobati rasa sakit akibat pidana yang di alaminya.

Pelaksanaan kunjungan di Lapas Kelas IIB Pangkalan Bun telah berjalan dengan baik yaitu dilaksanakan setiap hari Senin, Rabu dan Sabtu untuk tahanan dan Selasa, Kamis, serta Jumat untuk Narapidana. Namun mengingat faktor waktu, jarak dan ekonomi menjadi kendala, hendaknya dengan kebijakan pihak Lapas Kelas IIB Pangkaan Bun menambah waktu kunjungan agar banyak kesempatan bagi keluarga yang bekerja, sekolah ataupun berdomisili jauh dari Lapas Kelas IIB Pangkalan Bun untuk mengunjungi mendapatkan kepuasan setelah kesulitan bercengkrama dengan keluarga.

Bagi narapidana yang tidak dikunjungi peran petugas sangat dibutuhkan untuk dapat menjadi pengganti keluarga mereka dengan menjadi teman bicara untuk mengungkapkan curahan hati mereka. Dalam situasi seperti ini seorang petugas harus bisa menempatkan diri sebagai seorang orang tua, guru serta teman, karena jelas bahwa mereka harus berbicara dengan seseorang tentang masalahnya yang dialaminya, namun berkomunikasi akan menjadi sulit bagi narapidana terlebih apabila narapidana tidak mempercayai siapapun yang berada di Lembaga Pemasyarakatan. Petugas juga tidak boleh bersikap diskriminatif antara narapidana satu dengan lainnya, dengan kata lain petugas harus menunjukkan sikap merangkul dan bersahabat agar narapidana tidak merasa segan ataupun takut untuk mengungkapkan apa yang mereka rasakan, sehingga sekaligus diharapkan dapat mengantisipasi dan meredam tekanan dan kecemasan yang dialami narapidana karena tidak pernah mendapat kunjungan dari keluarganya. Selain itu juga, seharusnya narapidana memiliki kesempatan untuk bercerita pada ahli profesional (psikolog/pekerja sosial) tentang masalah yang sedang dihadapinya. Namun pada kenyataannya kondisi sebenarnya yang terjadi di lapangan, tenaga psikolog ataupun pekerja sosial tidak selalu ada di setiap unit pelayanan teknis (UPT). Oleh karena itu, sangat penting bagi narapidana untuk diberikan kesempatan berbicara secara pribadi dengan petugas Rumah Tahanan Negara.

Pelaksanaan kunjungan keluarga ini membawa pengaruh yang positif bagi kondisi psikologis narapidana selama mereka berada di Lembaga Pemasyarakatan. Namun pada kenyataannya pada saat penulis mengamati keadaan di lapangan, ada 
narapidana yang justru tidak suka ataupun tidak mau dikunjungi. Hal tersebut karena beberapa alasan seperti pada saat keluarga mereka datang mengunjungi selalu menunjukkan sikap kekecewaan, belum bisa menerima jika keluarganya berada di penjara dan terkadang masih suka menyalahkan narapidana atas kesalahan yang mereka perbuat. Hal lain juga di karenakan suami/istri mereka datang untuk meminta/membawa surat cerai karena tidak dapat menerima bahwa suami/istri mereka di penjara. Kejadian seperti itu menuntut petugas agar lebih memperhatikan dan peduli keadaan yang sedang terjadi pada diri narapidana dan hubungannya dengan keluarganya. Sehingga petugas dapat menyarankan kepada keluarga pada saat kunjungan mereka tidak menunjukkan sikap yang dapat membuat narapidana tidak nyaman dan tidak menyampaikan berita kurang baik pada saat kondisi psikologis narapidana tidak memungkinkan untuk menerimanya.

\section{Kesimpulan}

Pelaksanaan kunjungan keluarga membawa pengaruh terhadap kondisi psikologis narapidana. Terpisah dengan keluarga dan teman-teman dekat merupakan salah satu luka yang sangat parah dari sebuah pidana penjara. Oleh sebab itu, manfaat dari pelaksanaan kunjungan keluarga ini sangat tampak jelas karena keluarga sebagai orang yang paling dekat dengan narapidana akan menciptakan suasana baru dan perlahan dapat mengobati luka tersebut dimana mereka dapat mencurahkan isi hatinya dan segala keluh kesah, melepas rasa rindu, mendapatkan nasihat-nasihat serta dorongan semangat sehingga narapidana merasa terhibur dan dapat mengurangi beban psikis yang dirasakan akibat pemidanaan yang dijalaninya.

Adanya pengaruh yang tampak bagi kondisi psikologis narapidana yang sering, jarang dan tidak pernah dikunjungi sebagai pengaruh dari kunjungan keluarga. Narapidana yang sering dikunjungi relatif lebih tenang dalam menjalani masa pidananya. Selain itu, narapidana tersebut lebih mudah bersosialisasi dengan sesama warga binaan pemasyarakatan (WBP) maupun petugas sedangkan narapidana yang jarang atau tidak pernah dikunjungi umumnya berperilaku menyendiri dan pemurung. Bahkan ada pula yang pernah berpikiran untuk melarikan diri.

Kunjungan keluarga yang dilakukan di Lapas Kelas IIB Pangkalan Bun telah berjalan dengan cukup baik jika dilihat dari berbagai kendala yang ada. Kendala tersebut adalah keterbatasan tempat pelaksanaan kunjungan yang kurang optimal, faktor waktu, domisili serta keadaan ekonomi keluarga narapidana yang sangat berpengaruh terhadap frekuensi kunjungan yang dilakukan. Selain itu, adanya kecenderungan adanya perasan malu dan sikap kurang peduli dari keluarga narapidana.

Pelaksanaan kunjungan di Lapas Kelas IIB Pangkalan Bun telah berjalan, namun mengingat faktor waktu, jarak dan ekonomi menjadi kendala, hendaknya dengan kebijakan pihak Lapas Kelas IIB Pangkalan Bun menambah waktu kunjungan. Bagi narapidana yang tidak dikunjungi peran petugas sangat dibutuhkan, seorang petugas harus bisa menempatkan diri sebagai seorang orang tua, guru serta teman. Selain itu, 
Bahtiyar Mandala Sutra

mendatangkan dan memberikan kesempatan untuk bercerita pada ahli profesional (psikolog/pekerja sosial) tentang masalah yang sedang dihadapinya. 


\section{BIBLIOGRAFI}

Datunsolang, A. (2013). Perlindungan Hak Asasi Manusia Bagi Narapidana Dalam Sistem Pemasyarakatan (Studi Kasus Lembaga Pemasyatakatan Kelas II A Manado). Hukum, 21(4), 111-123.

Devilla, F. A., \& Tarmizi, T. (2018). Penerapan Sanksi Pidana Terhadap Kendaraan Yang Tidak Laik Jalan Karena Telah Dimodifikasi. Jurnal Ilmiah Mahasiswa Bidang Hukum Pidana, 2(4), 735-745.

Dwiatmojo, H. (2014). Community Base Treatment Dalam Pembinaan Narapidana Narkotika (Studi Terhadap Pembinaan Narapidana di Lembaga Pemasyarakatan Narkotika Klas IIA Yogyakarta). Jurnal Dinamika Hukum, 14(1), 110-122.

Hairina, Y., \& Komalasari, S. (2017). Kondisi Psikologis Narapidana Narkotika Di Lembaga Pemasyarakatan Narkotika Klas II Karang Intan, Martapura, Kalimantan Selatan. Jurnal Studia Insania, 5(1), 94-104.

Harefa, S. (2019). Penegakan Hukum Terhadap Tindak Pidana Di Indonesia Melaui Hukum Pidana Positif Dan Hukum Pidana Islam. University Of Bengkulu Law Journal, 4(1), 35-58.

Hilton, N. (2019). Pemenuhan Hak Asasi Narapidana Dan Tahanan Dalam Menerima Kunjungan Keluarga (Studi Di Lembaga Permasyarakatan Klass II A Padang). Abstract of Undergraduate Research, Faculty of Law, Bung Hatta University, 10(1).

Meilina, C. P. (2013). Dampak Psikologis Bagi Narapidana Wanita yang Melakukan Tindak Pidana Pembunuhan dan Upaya Penanggulangannya. Fakultas Hukum, Universitas Brawijaya, 1-15.

Michael, D. (2015). Penerapan Hak-Hak Narapidana di Lembaga Pemasyarakatan Klas IA Tanjung Gusta, Sumatera Utara Ditinjau dari Perspektif Hak Asasi Manusia. Jurnal HAM, 6(740), 91-104.

Nomor, U.-U. (12 C.E.). tahun 1995 tentang Pemasyarakatan. Videbeck, SL (2008). Buku Ajar Keperawatan Jiwa (Renata Komalasari \& Alfrina Hany, Penerjemah). Jakarta: EGC.

Nurrahma, E. (2013). Perbedaan Self Eteem Pada Narapidana Baru dan Residivis Di Lemabaga Pemasyarakatan Klas I Malang. Program Studi Psikologi Universitas Brawijaya Malang, 1-12.

Permana, R. A., \& Rudatyo, H. M. (2017). Pelaksanaan Sistem Layanan Kunjungan Bagi Warga Binaan Dalam Rangka Peningkatan Pelayanan Kepada Publik Berdasarkan UU No 12 Tahun 1995. Universitas Islam Batik Surakarta, 106-117.

Pohan, A., Santoso, T., \& Moerings, M. (2012). Hukum pidana dalam perspektif. Bali: 
Bahtiyar Mandala Sutra

Pustaka Larasan.

Pratama, F. A. (2016). Kesejahteraan Psikologis Pada Narapidana Di Lembaga Pemasyarakatan Kelas II A Sragen. Universitas Muhammadiyah Surakarta, 1-15.

Utami, P. N. (2017). Keadilan Bagi Narapidana di Lembaga Pemasyarakatan. Jurnal Penelitian Hukum De Jure, 17(3), 381.

Videbeck, S. L. (2008). Buku ajar keperawatan jiwa. Jakarta: Egc, 45, 2010-2011.

Wati, R. S. (2014). Perbandingan tingkat depresi antara narapidana non-residivis dan residivis di Lembaga Pemasyarakatan Kelas II A Banceuy.

Wuryansari, R., \& Subandi, S. (2019). Program Mindfulness for Prisoners (Mindfulners) untuk Menurunkan Depresi pada Narapidana. Gadjah Mada Journal of Professional Psychology (GamaJPP), 5(2), 196. 